\title{
Effect of nitrite on interaction between the giant freshwater prawn Macrobrachium rosenbergii and its pathogen Lactococcus garvieae
}

\author{
Winton Cheng ${ }^{1}$, Chun-Hung Liu ${ }^{2}$, Jiann-Chu Chen ${ }^{3, *}$ \\ ${ }^{1}$ Department of Aquaculture, and ${ }^{2}$ Institute of Tropic Agriculture, National Pingtung University of Science and Technology, \\ Pingtung, Taiwan 912, ROC \\ ${ }^{3}$ Department of Aquaculture, National Taiwan Ocean University, Keelung, Taiwan 202, ROC
}

\begin{abstract}
Addition of nitrite- $\mathrm{N}$ at $1.5 \mathrm{mg} \mathrm{l}^{-1}$ in tryptic soy broth $(\mathrm{TSB})$ significantly $(\mathrm{p}<0.05)$ decreased the growth rate of the bacterial pathogen Lactococcus garvieae and significantly $(\mathrm{p}<0.05)$ reduced mortality compared to zero nitrite controls when injected into giant freshwater prawns Macrobrachium rosenbergii at $5 \times 10^{5}$ colony-forming units (CFU) per prawn. In other experiments, whereby prawns were injected with TSB-grown L. garvieae $\left(5 \times 10^{5} \mathrm{CFU}\right.$ prawn $\left.^{-1}\right)$ and then held in water containing nitrite-N, mortality at $72 \mathrm{~h}$ post-injection was significantly $(\mathrm{p}<0.05)$ higher for prawns held in water containing $1.68 \mathrm{mg} \mathrm{l}^{-1}$ nitrite than at lower concentrations. Prawns exposed to different concentrations of nitrite- $\mathrm{N}$ were examined for THC (total hemocyte count), phenoloxidase activity, respiratory burst, phagocytic activity and bacterial clearance efficiency. No significant differences in THC and phenoloxidase activity were observed among treatments. With prawns exposed to nitrite-N for $168 \mathrm{~h} \mathrm{(7} \mathrm{d)} \mathrm{at} 1.59 \mathrm{mg} \mathrm{l}^{-1}$, phagocytic activity and clearance efficiency decreased, while at $1.15 \mathrm{mg} \mathrm{l}^{-1}$ or more, respiratory burst increased, generating the superoxide anion at levels considered cytoxic to the host. We conclude that nitrite- $\mathrm{N}$ at $1.68 \mathrm{mg} \mathrm{l}^{-1}$ causes depression in the immune response and increased mortality in $M$. rosenbergii infected with $L$. garvieae.
\end{abstract}

KEY WORDS: Macrobrachium rosenbergii $\cdot$ Lactococcus garvieae $\cdot$ Nitrite $\cdot$ Challenge $\cdot$ Virulence Hemocyte count $\cdot$ Phenoloxidase activity $\cdot$ Superoxide anion

\section{INTRODUCTION}

The giant freshwater prawn Macrobrachium rosenbergii is commercially important globally, and especially in Taiwan, as a primary inland-cultured species (New 1995). Disease outbreaks caused by yeast infections in the cool season and Enterococcus-like infections in the hot season have resulted in declining production of farmed prawns in Taiwan (Cheng \& Chen 1998a). Recently, by polymerase chain reaction assay and $16 \mathrm{~S}$ rDNA sequencing, the causative bacterium

${ }^{*}$ Corresponding author. E-mail: jcchen@mail.ntou.edu.tw was identified as Lactococcus garvieae (Chen et al. 2001).

In decapod crustaceans, 3 types of circulating hemocytes are recognized: hyaline, semi-granular and large granular cells (Tsing et al. 1989). They are involved in cellular immune responses that include phagocytosis and constitute the primary method of eliminating microorganisms or foreign particles (Bayne 1990). Normal hemocyte counts have been established for the shore crab Carcinus maenas (Truscott \& White 1990), common shrimp Crangon crangon (Smith \& Johnston 1992), and Macrobrachium rosenbergii (Cheng \& Chen 2000). 
In addition to phagocytosis, hemocytes are involved in coagulation and in the production of melanin via the prophenoloxidase system (Johansson \& Söderhäll 1989, Söderhäll et al. 1996). Enzymes for the prophenoloxidase system are contained in the granular hemocytes, released as proenzymes upon stimulation by microbial cell components such as $\beta-1,3$-glucan or lipopolysaccharide from fungal cell walls, and activated by a serine protease (Söderhäll 1983, Smith et al. 1984, Söderhäll et al. 1996). The activity of phenoloxidase has been reported for many crustaceans (Söderhäll et al. 1996) including the brown shrimp Penaeus californiensis (Hernández-López et al. 1996), the tiger shrimp P. monodon (Sritunyalucksana et al. 1999) and Macrobrachium rosenbergii (Cheng \& Chen 2002).

Several species of reactive oxygen intermediates (ROIs) are produced during phagocytosis. Once a pathogen or foreign particle enters a host, it activates the host's NADPH-oxidase which, in turn, produces several reactive oxygen intermediates such as the superoxide anion $\left(\mathrm{O}_{2}^{-}\right)$, hydrogen peroxide $\left(\mathrm{H}_{2} \mathrm{O}_{2}\right)$ and hydroxyl radical ( $\left.\mathrm{OH}^{*}\right)$ (Holmblad \& Söderhäll 1999). These compounds can be directly toxic to pathogens (Roch 1999). The generation of the superoxide anion is known as the respiratory burst, and it plays an important role in microbicidal activity. It has been reported in the hemocytes of the shore crab Carcinus maenas (Bell \& Smith 1993), the tiger shrimp Penaeus monodon (Song \& Hsieh 1994) and the blue shrimp P. stylirostris (Le Moullac et al. 1998).

Several physico-chemical parameters and environmental contaminants have been reported to affect the immune response in crustaceans and these have been reviewed by Le Moullac \& Haffner (2000). Environmental toxicants have been reported to cause a reduction in hemocyte count in the common shrimp Crangon crangon (Smith \& Johnston 1992) and the shore crab Carcinus maenas (Truscott \& White 1990, Victor et al. 1990, Le Moullac \& Haffner 2000). They have also been reported to cause reduction of phenoloxidase activity in C. crangon, C. maenas and Macrobrachium rosenbergii (Truscott \& White 1990, Smith \& Johnston 1992, Smith et al. 1995, Cheng \& Chen 2002).

Ammonia, the end product of protein catabolism, accounts for more than half the nitrogenous waste released by decapod crustaceans in intensive culture ponds (Regnault 1987). Although ammonia is toxic to crustaceans, it can be removed by bacterial nitrification or bacterial denitrification via nitrite, an intermediate in the nitrogen cycle. However, elevated concentrations of nitrite have also been reported to have negative effects on growth and molting (Chen \& Chen 1992), oxygen consumption and ammonia excretion (Cheng \& Chen 1998a), hemolymph hemocyanin and protein levels (Cheng \& Chen 1999), osmolality and ion concentration in penaeid shrimp and Macrobrachium rosenbergii (Chen \& Lee 1997, Cheng \& Chen 1998b). The $96 \mathrm{~h}$ median lethal concentration of nitrite- $\mathrm{N}$ for $M$. rosenbergii larvae and juveniles has been reported to be 8.6 and 8.5 to $12.9 \mathrm{mg} \mathrm{l}^{-1}$, respectively (Armstrong et al. 1976, Chen \& Lee 1997).

Ammonia has been reported to affect the immune response of Penaeus stylirostris (Le Moullac \& Haffner 2000) and Macrobrachium rosenbergii (Cheng \& Chen 2002). However, little is known regarding the effect of nitrite stress on the immune response and pathogen resistance of shrimp or prawns. Accordingly, this study examined the effects of nitrite on growth and virulence of Lactococcus garvieae and on the response of $M$. rosenbergii to L. garvieae.

\section{MATERIALS AND METHODS}

Lactococcus garvieae. L. garvieae was isolated from diseased Macrobrachium rosenbergii with opaque and whitish musculature (Cheng \& Chen 1998a). It was cultured on tryptic soy agar (TSA, Difco) for $24 \mathrm{~h}$ at $30^{\circ} \mathrm{C}$ before being transferred to $10 \mathrm{ml}$ tryptic soy broth (TSB, Difco) for $24 \mathrm{~h}$ at $30^{\circ} \mathrm{C}$ as a stock culture for tests. For challenge experiments, stock cultures were centrifuged at $7155 \times g$ for $15 \mathrm{~min}$ at $4^{\circ} \mathrm{C}$. The supernatant fluid was removed and the bacterial pellet was resuspended in saline solution $(0.85 \% \mathrm{NaCl})$ at $2.5 \times$ $10^{7} \mathrm{CFU} \mathrm{ml} \mathrm{m}^{-1}$ or $10^{9} \mathrm{CFU} \mathrm{ml} \mathrm{m}^{-1}$ as stock bacterial suspensions for injection challenges.

Macrobrachium rosenbergii. $M$. rosenbergii were obtained from a commercial farm in Pingtung, Taiwan, and acclimated in the laboratory for $2 \mathrm{wk}$ before experimentation. For bacterial challenge experiments, test and control groups comprised 10 prawns each in triplicate and individual prawns were in the intermolt stage (Stage C) and weighed 8 to $12 \mathrm{~g}$. After injection, each group of 10 prawns was kept in a separate 601 glass aquarium containing $40 \mathrm{l}$ aerated water. For immune parameter assays, prawns weighed 20 to $30 \mathrm{~g}$ and were in the intermolt stage. For immune activity assays, tests were carried out in triplicate or quadruplicate test groups consisting of 2 prawns each in separate 601 glass aquaria containing 401 aerated water. In all tests, prawns were fed twice daily with a formulated prawn diet (Shinta Feed Company) and observed for $168 \mathrm{~h}$ (7 d). During experiments, water temperature was maintained at $28 \pm 1^{\circ} \mathrm{C}$, pH 7.3 to 7.8 , total hardness of $100 \mathrm{mg} \mathrm{l}^{-1}$ (as $\mathrm{CaCO}_{3}$ ).

Effect of nitrite on growth of Lactococcus garvieae. Inoculum for the growth tests consisted of $0.5 \mathrm{ml}$ of stock broth culture. The stock solution of nitrite was prepared by dissolving $4.93 \mathrm{~g} \mathrm{NaNO}_{2}$ (Merck reagent grade) in 11 distilled water to achieve a concentration 
of $1000 \mathrm{mg} \mathrm{l}^{-1}$ nitrite-N. Bacteria were incubated in $50 \mathrm{ml}$ TSB with different concentrations of nitrite- $\mathrm{N}$ (zero control, 0.3, 0.6, 1.0 and $1.5 \mathrm{mg} \mathrm{l}^{-1}$ ) in $250 \mathrm{ml}$ flasks at $30^{\circ} \mathrm{C}$. Each test was conducted in triplicate and bacterial growth was monitored at 12, 24, 48 and $120 \mathrm{~h}$ incubation by measuring the optical density (OD) at $601 \mathrm{~nm}$ using a Model U-2000 spectrophotometer (Hitachi).

Effect of nitrite on virulence of Lactococcus garvieae. After $24 \mathrm{~h}$ of cultivation in TSB containing different concentrations of nitrite-N, L. garvieae was harvested by centrifugation at $7155 \times g$ for $15 \mathrm{~min}$ at $4{ }^{\circ} \mathrm{C}$. The pellet was re-suspended in saline solution $(0.85 \% \mathrm{NaCl})$ at $2.5 \times 10^{7} \mathrm{CFU} \mathrm{ml}^{-1}$ as the stock bacterial suspension for injection. The concentration of bacterial suspension was measured by its absorbance at $601 \mathrm{~nm}$ optical density, and was calculated as a standard curve based on a series of different concentrations of bacterial suspension.

Into the ventral sinus of the cephalothorax of each prawn, we injected $20 \mu \mathrm{l}$ of bacterial suspension $(5 \times$ $10^{5} \mathrm{CFU}$ prawn $^{-1}$ ) following the method of Cheng \& Chen (1998b). Control prawns were injected with an equal volume of sterile saline solution (see Table 1).

Effect of nitrite on resistance of Macrobrachium rosenbergii to Lactococcus garvieae. $M$. rosenbergii were injected with $L$. garvieae at $5 \times 10^{5} \mathrm{CFU}$ prawn $^{-1}$ using $20 \mu \mathrm{l}$ of bacterial stock solution $\left(2.5 \times 10^{7} \mathrm{CFU}\right.$ $\mathrm{ml}^{-1}$ ), and then kept in $60 \mathrm{l}$ glass aquaria containing 401 of water with different added concentrations of nitrite-N (zero control and 0.3, 0.6, 1.0 and $1.5 \mathrm{mg} \mathrm{l}^{-1}$ ) that was renewed daily for $7 \mathrm{~d}(168 \mathrm{~h})$. The actual mean measured concentrations of nitrite- $\mathrm{N}$ were 0.01 (control), 0.29, 0.66, 1.15 and $1.68 \mathrm{mg} \mathrm{l}^{-1}$, respectively (Bendscheider \& Robinson 1952). Prawns injected with an equal volume of sterile saline solution and kept in water containing $1.68 \mathrm{mg} \mathrm{l}^{-1}$ nitrite-N served as an unchallenged control (see Table 2).

Effect of nitrite on immune parameters of Macrobrachium rosenbergii. For hemocyte counts and enzyme activity assays, $M$. rosenbergii (20 to $30 \mathrm{~g}$, intermolt stage) were placed in triplicate in aquaria (2 prawns per aquarium) with added nitrite-N (zero control and $0.3,0.6,1.0$ and $1.5 \mathrm{mg} \mathrm{l}^{-1}$ ) that was renewed daily for $7 \mathrm{~d}(168 \mathrm{~h})$. The actual mean measured concentrations of nitrite- $\mathrm{N}$ in each test solution were the same as given in the preceding subsection for the studies on THC, phenoloxidase activity and respiratory burst (see Table 2); for the phagocytic activity and clearance efficiency studies, they were 0.01 (control), $0.31,0.62,1.08$ and $1.59 \mathrm{mg} \mathrm{l}^{-1}$.

Hemolymph was sampled individually at the beginning of the test and again at $168 \mathrm{~h}$. Hemolymph $(100 \mu \mathrm{l})$ was withdrawn from the ventral sinus of each prawn into a $1 \mathrm{ml}$ sterile syringe (25 gage) containing
$0.9 \mathrm{ml}$ anticoagulant solution $(0.114 \mathrm{M}$ trisodium citrate, $0.1 \mathrm{M}$ sodium chloride, $\mathrm{pH}$ 7.45, osmolality 490 mOsm $\mathrm{kg}^{-1}$ ). A drop of hemolymph was placed on a hemocytometer, and THC was measured using an inverted phase-contrast microscope (Leica DMIL).

To measure phenoloxidase activity spectrophotometrically by recording the formation of dopachrome produced from L-dihydroxyphenylalanine (L-DOPA) (Hernãndez-López et al. 1996), diluted hemolymph was centrifuged at $300 \times g$ at $4^{\circ} \mathrm{C}$ for $10 \mathrm{~min}$; the supernatant fluid was then discarded and the pellet was rinsed, resuspended gently in $1 \mathrm{ml}$ cacodylate-citrate buffer (0.01 M sodium cacodylate, $0.45 \mathrm{M}$ sodium chloride, $0.10 \mathrm{M}$ trisodium citrate, $\mathrm{pH}$ 7.0) and centrifuged again. The pellet was then re-suspended in $200 \mu \mathrm{l}$ cacodylate buffer (0.01 M sodium cacodylate, $0.45 \mathrm{M}$ sodium chloride, $0.01 \mathrm{M}$ calcium chloride, $0.26 \mathrm{M}$ magnesium chloride, $\mathrm{pH} 7.0$ ), and a $100 \mu \mathrm{l}$ aliquot was incubated with $50 \mu \mathrm{l}$ trypsin $\left(1 \mathrm{mg} \mathrm{ml}^{-1}\right)$, which served as an activator, for $10 \mathrm{~min}$ at 25 to $26^{\circ} \mathrm{C} ; 50 \mu \mathrm{l}$-DOPA was then added, followed by $800 \mu$ l cacodylate buffer 5 min later. The optical density at $490 \mathrm{~nm}$ was measured using a Hitachi U-2000 spectrophotometer. The control solution, which consisted of $100 \mu$ l cell suspension, $50 \mu$ cacodylate buffer (to replace the trypsin) and $50 \mu \mathrm{l}$ L-DOPA, was used to measure the background phenoloxidase activity in all test conditions. The optical density of the background phenoloxidase activity was in the range of 0.02 to 0.08 . The optical density of the prawns, phenoloxidase activity for all test conditions was expressed as dopachrome formation in $50 \mu \mathrm{l}$ of hemolymph.

Respiratory burst activity of hemocytes was quantified using the reduction of nitroblue tetrazolium (NBT) to formazan as a measure of the superoxide anion, as described previously (Bell \& Smith 1993, Song \& Hsieh 1994). Briefly, $100 \mu$ hemolymph in anticoagulant solution was deposited in triplicate on microplates previously coated with $100 \mu \mathrm{l}$ poly-Llysine solution $(0.2 \%)$ to improve cell adhesion. Microplates were centrifuged at $300 \times g$ for $15 \mathrm{~min}$. Plasma was removed and $100 \mu \mathrm{l}$ zymosan $(0.1 \%$ in Hank's solution minus phenol red) was added and allowed to react for $30 \mathrm{~min}$ at room temperature. Zymosan was discarded and the hemocytes were washed 3 times with $100 \mu$ l Hank's solution and stained with $100 \mu \mathrm{l}$ NBT solution $(0.3 \%)$ for $30 \mathrm{~min}$ at room temperature. The NBT solution was removed and the hemocytes were fixed, washed 3 times with $100 \mu \mathrm{l} 70 \%$ methanol and air-dried. Formazan was dissolved by the addition of $120 \mu \mathrm{l} 2 \mathrm{M} \mathrm{KOH}$ and 140 $\mu l$ dimethyl sulfoxide. The optical density at $630 \mathrm{~nm}$ was measured using a microplate reader (Dynex Mrx II). Respiratory burst was expressed as NBT reduction $10 \mathrm{\mu l}^{-1}$ of hemolymph. 
To measure bacterial clearance and phagocytic activity, experimental parameters were as described above except that tests were carried out in quadruplicate. For bacterial clearance tests, prawns at $168 \mathrm{~h}$ exposure were injected in the muscle of the second abdominal segment with $20 \mu$ bacterial suspension $\left(10^{9} \mathrm{CFU} \mathrm{ml} \mathrm{m}^{-1}\right.$ in $\left.0.85 \% \mathrm{NaCl}\right)$, resulting in $10^{7} \mathrm{CFU}$ prawn $^{-1}$. After injection, the prawns were held in their respective test solutions for $3 \mathrm{~h}$ at $27 \pm 1^{\circ} \mathrm{C}$, before collecting $200 \mu \mathrm{l}$ volume of hemolymph from the ventral sinus and mixing with $200 \mu \mathrm{l}$ sterile anticoagulant (modified alsever solution [MAS] or MAS containing $0.8 \mathrm{~g}$ sodium citrate, $0.34 \mathrm{~g}$ EDTA, $8010 \mu \mathrm{l}$ Tween, $100 \mathrm{ml}$ distilled water, $\mathrm{pH} 7.45,490 \mathrm{mOsm} \mathrm{kg}{ }^{-1}$ ). This mixture was divided into 2 equal sub-samples, one to measure phagocytic activity and the other to measure clearance efficiency. With 2 prawns in each of 4 replicates, this gave 8 measurements per parameter for each treatment.

Phagocytic activity was measured following the method described by Weeks-Perkins et al. (1995). Briefly, $200 \mu \mathrm{l}$ of the diluted hemolymph sample was mixed with $0.2 \mathrm{ml} 0.1 \%$ paraformaldehyde for $30 \mathrm{~min}$ at $4{ }^{\circ} \mathrm{C}$ to fix the hemocytes. They were then centrifuged at $800 \times g$ (Centrifuge Model Z323 K, Hermle at $4^{\circ} \mathrm{C}$, washed and resuspended in $0.4 \mathrm{ml}$ sterile phosphate buffer solution (PBS). Then, $50 \mu \mathrm{l}$ of the suspension was spread on a glass slide. The slide was placed in a cytospin centrifuge (Model Cytospin 3, Shandon) and centrifuged at $113 \times g$ for $3 \mathrm{~min}$. The slide was then air-dried, stained with Diff-Quick stain, and

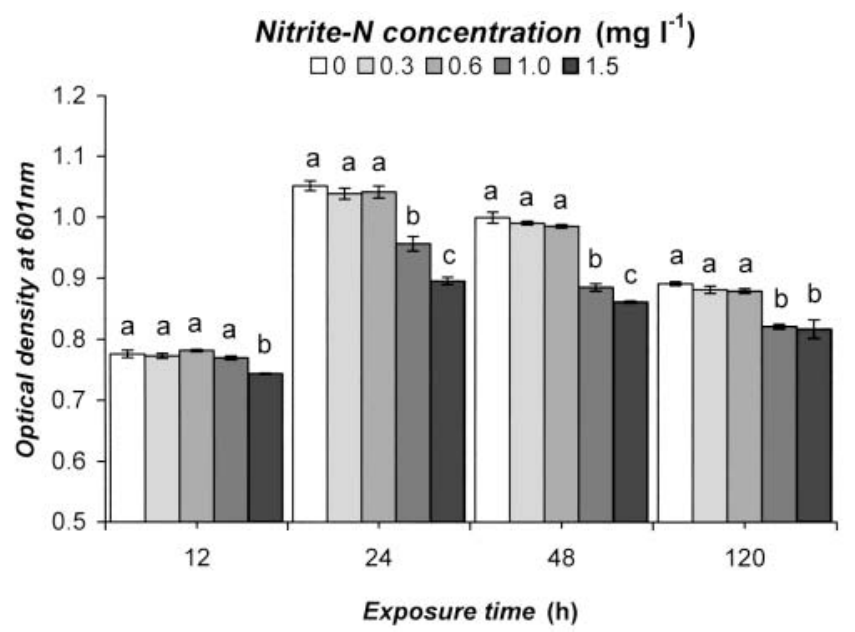

Fig. 1. Lactococcus garvieae. Effect of nitrite-N on growth at $30^{\circ} \mathrm{C}$ in TSB medium. Bacterial numbers were determined by absorbance of bacterial suspension at $601 \mathrm{~nm}$ OD at 12, 24, 48 and $120 \mathrm{~h}$. Each bar represents the mean $( \pm \mathrm{SE})$ of 3 determinations. Bars for same time with different letters are significantly different $(p<0.05)$ observed using a light microscope; 200 hemocytes were counted and the phagocytic rate (PR) was expressed as:

$\mathrm{PR}=[($ phagocytic hemocytes $) /($ total hemocytes $)] \times 100$

Clearance efficiency was measured following the method of Adams et al. (1991). Three $50 \mu \mathrm{l}$ portions of each diluted hemolymph sample were spread on separate TSA plates and incubated at $30^{\circ} \mathrm{C}$ for $24 \mathrm{~h}$ before colonies were counted using a colony counter. Clearance efficiency, defined as percentage inhibition (PI) of Lactococcus garvieae was calculated as:

$$
\begin{gathered}
\mathrm{PI}=100-[(\mathrm{CFU} \text { in test group }) / \\
(\mathrm{CFU} \text { in control group })] \times 100
\end{gathered}
$$

Statistical analysis. A multiple-comparison Tukey test was used to examine for significant differences among treatments (SAS computer software). Differences were considered significant when $\mathrm{p}<0.05$.

\section{RESULTS}

\section{Effect of nitrite on growth of Lactococcus garvieae}

Lactococcus garvieae grew well in TSB medium containing nitrite- $\mathrm{N}$ concentrations of 0.3 , and $0.6 \mathrm{mg} \mathrm{l}^{-1}$ but there was some retardation at 1.0 and $1.5 \mathrm{mg} \mathrm{l}^{-1}$. Bacterial density reached a maximum at $24 \mathrm{~h}$ in all test media and declined thereafter (Fig. 1).

\section{Effect of nitrite on virulence of Lactococcus garvieae}

All unchallenged control prawns survived. In contrast, deaths began to occur in the challenged prawns at $48 \mathrm{~h}$. Cumulative mortality after $120 \mathrm{~h}$ was significantly lower with bacteria incubated in TSB containing nitrite-N at 1.0 to $1.5 \mathrm{mg} \mathrm{l}^{-1}$ than with bacteria incubated at lower concentrations (Table 1).

\section{Effect of nitrite on resistance of Macrobrachium rosenbergii to Lactococcus garvieae}

All unchallenged control prawns survived. In contrast, onset of mortality occurred at 12 to $24 \mathrm{~h}$ in the challenged prawns (Table 2). Onset of mortality of prawns in $1.68 \mathrm{mg} \mathrm{l}^{-1}$ nitrite-N was much earlier $(12 \mathrm{~h})$ than at lower concentrations, and mean cumulative mortality was always highest for this group, although the difference was not statistically significant until after $48 \mathrm{~h}$. There were no significant differences in cumulative mortality between the challenged prawns at other concentrations of nitrite-N. 


\section{Effect of nitrite on immune parameters of Macrobrachium rosenbergii}

There were no significant differences in THC for any of the prawns in the study as a function of nitrite-N concentration or time of exposure; the mean $( \pm \mathrm{SE})$ THC varied from $82 \pm 12 \times 10^{5}$ to $95 \pm 5 \times 10^{5}$ cells ml $^{-1}$ (Table 3 ). Neither were there any significant differences in phenoloxidase activity for any of the prawns

Table 1. Macrobrachium rosenbergii challenged with Lactococcus garvieae. Cumulative mortality (\%) in prawns after injection of $5 \times 10^{5} \mathrm{CFU}$ of the pathogen incubated in tryptic soy broth at different concentrations of nitrite$\mathrm{N}$. Controls were injected with equal volume of sterile saline solution. Data in same column with different letters are significantly different $(p<0.05)$ among the treatments. Values are means $\pm \mathrm{SE}$

\begin{tabular}{|lcccccc|}
\hline \multirow{2}{*}{$\begin{array}{l}\text { Nitrite-N } \\
\left(\mathrm{mg} \mathrm{l}^{-1}\right)\end{array}$} & 48 & 72 & 96 & 120 & 144 & 168 \\
\hline $\begin{array}{l}\text { Unchallenged } \\
\text { control }\end{array}$ & 0 & 0 & 0 & 0 & 0 & 0 \\
0 & $7 \pm 7^{\mathrm{a}}$ & $13 \pm 9^{\mathrm{a}}$ & $30 \pm 6^{\mathrm{a}}$ & $30 \pm 6^{\mathrm{a}}$ & $30 \pm 6^{\mathrm{a}}$ & $30 \pm 6^{\mathrm{a}}$ \\
0.3 & $3 \pm 3^{\mathrm{a}}$ & $17 \pm 3^{\mathrm{a}}$ & $17 \pm 3^{\mathrm{ab}}$ & $33 \pm 3^{\mathrm{a}}$ & $33 \pm 3^{\mathrm{a}}$ & $33 \pm 3^{\mathrm{a}}$ \\
0.6 & $10 \pm 6^{\mathrm{a}}$ & $17 \pm 9^{\mathrm{a}}$ & $20 \pm 0^{\mathrm{a}}$ & $30 \pm 6^{\mathrm{a}}$ & $30 \pm 6^{\mathrm{a}}$ & $30 \pm 6^{\mathrm{a}}$ \\
1.0 & $7 \pm 3^{\mathrm{a}}$ & $10 \pm 6^{\mathrm{a}}$ & $13 \pm 3^{\mathrm{ab}}$ & $17 \pm 3^{\mathrm{b}}$ & $20 \pm 0^{\mathrm{ab}}$ & $20 \pm 0^{\mathrm{ab}}$ \\
1.5 & $3 \pm 3^{\mathrm{a}}$ & $7 \pm 7^{\mathrm{a}}$ & $10 \pm 6^{\mathrm{b}}$ & $17 \pm 3^{\mathrm{b}}$ & $17 \pm 3^{\mathrm{b}}$ & $17 \pm 3^{\mathrm{b}}$ \\
& & & & & & \\
\hline
\end{tabular}

Table 2. Macrobrachium rosenbergii. Cumulative mortality (\%) in prawns challenged with Lactococcus garvieae at $5 \times 10^{5} \mathrm{CFU}$ prawn ${ }^{-1}$, and then held at different concentrations of nitrite-N. Unchallenged controls were injected with equal volume of sterile saline solution and kept in water with $1.68 \mathrm{mg} \mathrm{l}^{-1}$ nitrite-N. Data in same column with different letters are significantly different $(p<0.05)$ among treatments. Values are means \pm SE

\begin{tabular}{|lcrcccc|}
\hline \multirow{2}{*}{$\begin{array}{l}\text { Nitrite-N } \\
\left(\mathrm{mg} \mathrm{l}^{-1}\right)\end{array}$} & 12 & 24 & 48 & 72 & 120 & 168 \\
\hline $\begin{array}{l}\text { Unchallenged } \\
\text { control (1.68) }\end{array}$ & 0 & 0 & 0 & 0 & 0 & 0 \\
0.01 (control) & $0 \pm 0^{\mathrm{a}}$ & $7 \pm 3^{\mathrm{a}}$ & $7 \pm 3^{\mathrm{b}}$ & $10 \pm 0^{\mathrm{b}}$ & $27 \pm 3^{\mathrm{b}}$ & $33 \pm 3^{\mathrm{b}}$ \\
0.29 & $0 \pm 0^{\mathrm{a}}$ & $10 \pm 6^{\mathrm{a}}$ & $10 \pm 6^{\mathrm{b}}$ & $17 \pm 3^{\mathrm{b}}$ & $30 \pm 6^{\mathrm{b}}$ & $37 \pm 3^{\mathrm{b}}$ \\
0.66 & $0 \pm 0^{\mathrm{a}}$ & $10 \pm 6^{\mathrm{a}}$ & $20 \pm 6^{\mathrm{ab}}$ & $20 \pm 6^{\mathrm{b}}$ & $33 \pm 7^{\mathrm{b}}$ & $40 \pm 6^{\mathrm{b}}$ \\
1.15 & $0 \pm 0^{\mathrm{a}}$ & $7 \pm 3^{\mathrm{a}}$ & $10 \pm 6^{\mathrm{b}}$ & $13 \pm 3^{\mathrm{b}}$ & $27 \pm 3^{\mathrm{b}}$ & $40 \pm 6^{\mathrm{b}}$ \\
1.68 & $10 \pm 6^{\mathrm{a}}$ & $20 \pm 6^{\mathrm{a}}$ & $23 \pm 3^{\mathrm{a}}$ & $40 \pm 6^{\mathrm{a}}$ & $50 \pm 6^{\mathrm{a}}$ & $57 \pm 3^{\mathrm{a}}$ \\
\hline
\end{tabular}

in the study as a function of nitrite- $\mathrm{N}$ concentration or from $0.39 \pm 0.03$ to $0.41 \pm 0.04$

There were no significant differences in respiratory burst measured at 0 and $168 \mathrm{~h}$ for prawns placed in zero control water and 0.29 or $0.66 \mathrm{mg} \mathrm{l}^{-1}$ nitrite-N (Fig. 2). However, the respiratory burst at $168 \mathrm{~h}$ was significantly higher (41 to $46 \%$ ) than that at $0 \mathrm{~h}$ for prawns exposed to nitrite-N at 1.15 and $1.68 \mathrm{mg} \mathrm{l}^{-1}$

With respect to phagocytic activity, no significant differences were observed for prawns placed in control water and water containing $0.31,0.62$, and $1.08 \mathrm{mg} \mathrm{l}^{-1}$ nitrite-N. However, there was significantly lower phagocytic activity (57\%) for prawns at $1.59 \mathrm{mg} \mathrm{l}^{-1}$ nitrite- $\mathrm{N}$ than for prawns in the group with no added nitrite (Fig. 3A).

A similar trend was seen for clearance of Lactococcus garvieae, whereby the only significant difference was decreased clearance $(155 \%)$ in the $1.59 \mathrm{mg} \mathrm{l}^{-1}$ nitrite-N group compared to the group with no added nitrite (Fig. 3B).

\section{DISCUSSION}

Culture media parameters can affect the growth of pathogens and their production of bacterial enzymes and toxins (Weinberg 1985, Arp 1988). Cheng \& Chen (1999) reported that optimum conditions for Lactococcus garvieae growth in brain/heart infusion broth (BHIB) were $\mathrm{pH} 7$ to 8 at 25 to $30^{\circ} \mathrm{C}$. They also reported (Cheng \& Chen 2002) that it grew well in tryptic soy broth (TSB) containing ammonia-N at concentrations as high as $5.14 \mathrm{mg} \mathrm{l}^{-1}$. In the present study, we found that growth of $L$. garvieae was depressed in TSB containing nitrite-N at only $\geq 1.0 \mathrm{mg} \mathrm{l}^{-1}$ (about $\geq 0.07 \mathrm{mM}$ ). Doßmann et al. (1996) reported a minor effect of

Table 3. Macrobrachium rosenbergii. Effect of different concentrations of nitrite-N on THC and phenoloxidase activity. Differences in each category are not significant $(p>0.05)$. Values are means \pm SE

\begin{tabular}{|lcccccc|}
\hline $\begin{array}{l}\text { Immune } \\
\text { parameter }\end{array}$ & $\begin{array}{c}\text { Exposure } \\
\text { time }(\mathrm{h})\end{array}$ & Control & 0.29 & 0.66 & \multicolumn{2}{c|}{ Nitrite-N concentrations $\left(\mathrm{mg} \mathrm{l}^{-1}\right)$} \\
\hline THC & 0 & $86 \pm 5$ & $92 \pm 12$ & $91 \pm 6$ & $95 \pm 5$ & 1.15 \\
$\left(\times 10^{5} \mathrm{ml}^{-1}\right)$ & 168 & $94 \pm 9$ & $93 \pm 9$ & $93 \pm 10$ & $88 \pm 10$ & $82 \pm 12$ \\
Phenoloxidase & 0 & $0.39 \pm 0.03$ & $0.40 \pm 0.04$ & $0.40 \pm 0.02$ & $0.40 \pm 0.04$ & $0.41 \pm 0.05$ \\
activity & 168 & $0.41 \pm 0.04$ & $0.40 \pm 0.05$ & $0.41 \pm 0.04$ & $0.41 \pm 0.04$ & $0.40 \pm 0.03$ \\
\hline
\end{tabular}




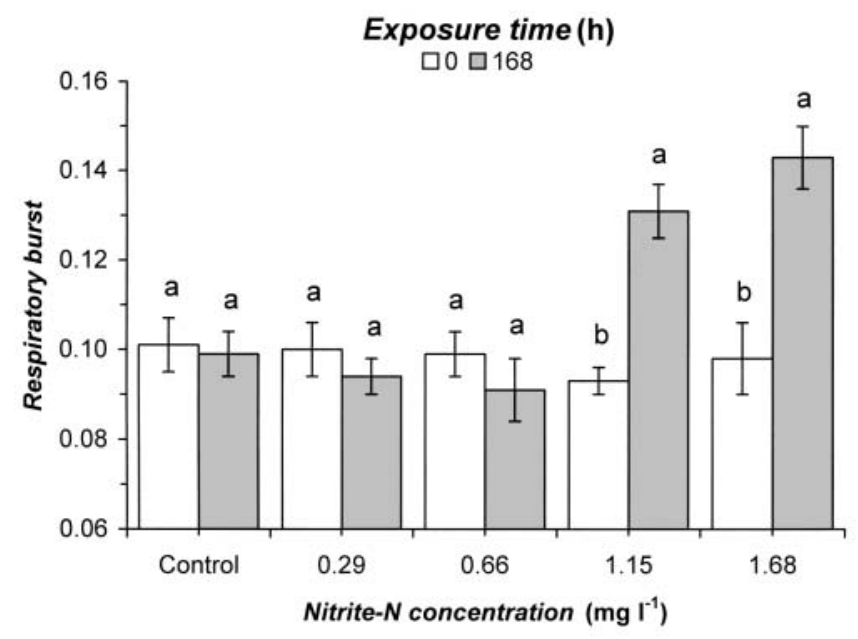

Fig. 2. Macrobrachium rosenbergii. Mean respiratory burst (as nitroblue tetrazolium reduction in $10 \mu \mathrm{l}$ hemolymph) in hemocytes at 0 and $168 \mathrm{~h}$ exposure to different concentrations of nitrite-N. Each bar represents the mean $( \pm \mathrm{SE})$ of 6 determinations. Bars for same nitrite- $\mathrm{N}$ concentration with different letters are significantly different $(p<0.05)$

sodium nitrite on the growth of both $L$. sake and $L$. pentosus, although the concentration that affected growth was not given. Blasco et al. (2001) reported that Rhodococcus sp. was able to grow in media in the presence of high concentrations of nitrate (up to $0.9 \mathrm{M}$ ) and $60 \mathrm{mM}$ nitrite $\left(840 \mathrm{mg} \mathrm{l}^{-1}\right)$. This suggests that $L$. garvieae may be rather sensitive to the concentration of nitrite in growth media.

Cheng \& Chen (1999) reported that incubation of Lactococcus garvieae under optimal conditions in BHIB containing 0.5 to $1.0 \mathrm{NaCl}$ significantly enhanced its virulence for Macrobrachium rosenbergii. Cheng \& Chen (2002) also reported that prior incubation of L. garvieae in TSB containing ammonia-N at $1.28 \mathrm{mg} \mathrm{l}^{-1}$ or more decreased its virulence when injected into $M$. rosenbergii. Herein we describe a similar effect upon prior incubation of L. garvieae in TSB containing $1.5 \mathrm{mg} \mathrm{l}^{-1}$ nitrite-N. However, the mechanism by which ammonia and nitrite may decrease the virulence of $L$. garvieae to $M$. rosenbergii is not known.

Kautsky et al. (2000) reported that fluctuations in normal environmental conditions such as oxygen, temperature and salinity had a significant effect on the virulence of the luminous bacterium Vibrio harveyi, with higher salinity increasing virulence to shrimp more than higher temperatures. On the other hand, Prayitno \& Latchford (1995) demonstrated that exposure of $V$. harveyi to low salinity (10 and $15 \mathrm{ppt}$ ) for $12 \mathrm{~h}$ prior to immersion challenge tests with larvae of the tiger shrimp Penaeus monodon resulted in higher mortalities, while exposure to $\mathrm{pH} 5.5$ reduced pathogenicity.
With respect to the prawns themselves, Cheng \& Chen (1998b) reported that Macrobrachium rosenbergii was most susceptible to Lactococcus garvieae when reared at $\mathrm{pH} 8.8$ to 9.5 and 33 to $34^{\circ} \mathrm{C}$. They also showed (Cheng \& Chen 2002) that $M$. rosenbergii was most susceptible to L. garvieae when the rearing water contained ammonia-N at $1.68 \mathrm{mg} \mathrm{l}^{-1}$ or more. Herein, we found a similar phenomenon, with $M$. rosenbergii being more susceptible to $L$. garvieae when reared in water containing nitrite- $\mathrm{N}$ at $1.68 \mathrm{mg} \mathrm{l}^{-1}$. We may conclude that the susceptibility of $M$. rosenbergii to $L$. garvieae is increased by high $\mathrm{pH}$, high temperature and the presence of relatively low levels of ammonia-N and nitrite- $\mathrm{N}$ in water.

The abundance of circulating hemocytes of Macrobrachium rosenbergii at different body sizes, seasons, body weights and molting cycle stages have been reported by Cheng \& Chen (2001). M. rosenbergii displayed the highest and lowest THC in autumn and winter, respectively. There were no significant differences between male and female prawns or among individuals with body weights ranging from 7 to $115 \mathrm{~g}$. M. rosenbergii displayed the lowest THC at the $\mathrm{D}_{3}$ molt stage and the highest at Stage C (Cheng \& Chen 2001). In the present study the $M$. rosenbergii used
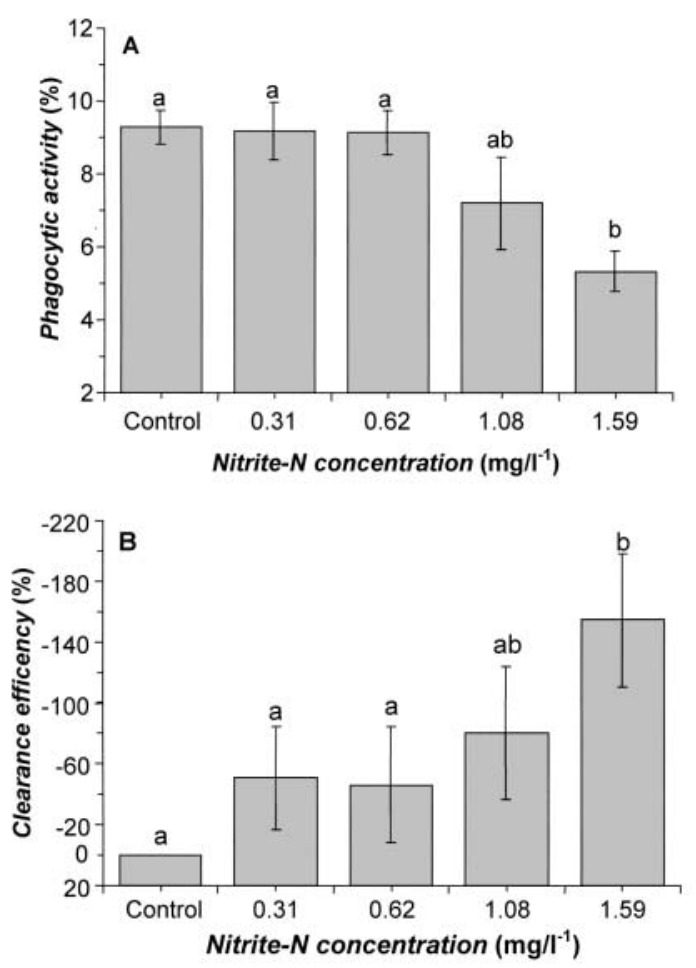

Fig. 3. Macrobrachium rosenbergii. Mean phagocytic activity (A) and clearance efficiency (B) of prawns infected with Lactococcus garvieae after the prawns had been placed in different concentrations of nitrite- $\mathrm{N}$ for $168 \mathrm{~h}$. Each bar represents the mean $( \pm \mathrm{SE})$ of 8 determinations. Bars with different letters are significantly different $(\mathrm{p}<0.05)$ 
were at Stage $\mathrm{C}$, and therefore were considered to have a similar host defense capability.

Circulating hemocytes can be affected by extrinsic factors such as temperature, $\mathrm{pH}$, salinity, dissolved oxygen and ammonia in several species of decapod crustaceans (Truscott \& White 1990, Le Moullac et al. 1998, Le Moullac \& Haffner 2000, Cheng \& Chen 2001). Macrobrachium rosenbergii reared at temperatures of 27 to $28^{\circ} \mathrm{C}$ and 30 to $31^{\circ} \mathrm{C}$ had significantly higher THC than those reared at 20 to $21^{\circ} \mathrm{C}$ or 33 to $34^{\circ} \mathrm{C}$. Prawns reared at $\mathrm{pH} 7.5$ to 7.7 had significantly higher THC than those reared at $\mathrm{pH} 4.6$ to 5.0 and 9.0 to 9.5 (Cheng \& Chen 2000). In contrast, there were no significant differences in THC among prawn groups exposed to ammonia- $\mathrm{N}$ concentrations in the range of 0.07 to $3.18 \mathrm{mg} \mathrm{l}^{-1}$ for $168 \mathrm{~h}$ (Cheng \& Chen 2002), and similar results were obtained herein for nitrite- $\mathrm{N}$ concentration in the range of 0.01 to $1.68 \mathrm{mg} \mathrm{l}^{-1}$.

Smith \& Johnston (1992) reported that exposure of the common shrimp Crangon crangon to PCB-15 (polychlorinated biphenyl-15) resulted in significantly decreased THC and phenoloxidase activity. Cheng \& Chen (2000) reported that both the phenoloxidase activity and THC of Macrobrachium rosenbergii were significantly higher at $\mathrm{pH} 7.5$ to 7.7 and 30 to $31^{\circ} \mathrm{C}$ than at $\mathrm{pH} 4.6$ to 5.0 or $\mathrm{pH} 9.0$ to 9.5 and 33 to $34^{\circ} \mathrm{C}$. Cheng \& Chen (2002) indicated that phenoloxidase activity of M. rosenbergii was significantly decreased by exposure to ammonia-N at $0.55 \mathrm{mg} \mathrm{l}^{-1}$ or more, in spite of the fact that ammonia-N did not affect THC. Le Moullac \& Haffner (2000) suggested that phenoloxidase and peroxinectin activity were reduced by ammonia at the level of gene expression in Penaeus stylirostris. Although we expected that nitrite- $\mathrm{N}$ exposure might reduce phenoloxidase activity in $M$. rosenbergii, this was not found to be the case.

Song \& Hsieh (1994) reported that $\beta$-glucan had the strongest stimulative effect on hemocytes in Penaeus monodon for generating $\mathrm{O}_{2}{ }^{-}$(superoxide anion) and $\mathrm{H}_{2} \mathrm{O}_{2}$ (hydrogen peroxide) that were considered to play a more important role in shrimp microbicidal activity than $\mathrm{OCl}^{-}$(hypochlorites) and MPO (myeloperoxidase). Le Moullac et al. (1998) proposed that the decreased production of the superoxide anion in hypoxic $P$. stylirostris was due to the decrease in THC, and that the NADPH oxidase responsible for production of the superoxide anion was not affected by hypoxia. Cheng \& Chen (2002) reported that exposure of Macrobrachium rosenbergii to $0.55 \mathrm{mg} \mathrm{l}^{-1}$ ammonia$\mathrm{N}$ for $168 \mathrm{~h}$ stimulated the production of the superoxide anion. Herein, we found that exposure of M. rosenbergii to 1.15 and $1.68 \mathrm{mg} \mathrm{l}^{-1}$ nitrite- $\mathrm{N}$ for $168 \mathrm{~h}$ also increased the superoxide anion. Thus, exposure of $M$. rosenbergii to appropriate concentrations of ammonia$\mathrm{N}$ or nitrite- $\mathrm{N}$ may increase cytotoxic immunity
(Muñoz et al. 2000). A small increase in the superoxide anion is considered to be beneficial with respect to increased immunity. However, too great an increase may be cytoxic to the host (Cheng \& Wang 2001). From our experiments, it is not possible to distinguish whether the increase in the superoxide anion resulted from increased NADPH oxidase activity or from decreased activity of superoxide dismutase (SOD) responsible for scavenging the superoxide anion. Further research is needed to examine the activities of superoxide dimutase, catalase and peroxidase (Holmblad \& Söderhäll 1999) in response to ammonia and nitrite stress.

Phagocytosis is an important cellular defense mechanism in crustaceans (Ratcliffe et al. 1985) that can be affected by environmental parameters. A significant reduction in phagocytosis of Bacillus cereus was observed in the shore crab Carcinus maenas following $14 \mathrm{~d}$ exposure to $500 \mathrm{\mu g}^{-1} \mathrm{Cd}^{2+}$ and $10 \mathrm{~d}$ exposure to $100 \mu \mathrm{g} \mathrm{I}^{-1} \mathrm{Cu}^{2+}$ (Truscott \& White 1990). Direkbusarakom \& Danayadol (1998) reported that phagocytosis of Saccharomyces cerevisiae, and clearance efficiency of Vibrio harveyi decreased in Penaeus monodon following exposure to 1.8 to $2.0 \mathrm{mg} \mathrm{l}^{-1} \mathrm{O}_{2}$ for $6 \mathrm{~h}$, compared to control shrimp. Similarly, we found that phagocytic activity and clearance efficiency of Lactococcus garvieae decreased in Macrobrachium rosenbergii following exposure to $1.59 \mathrm{mg} \mathrm{l}^{-1}$ nitrite-N. This correlated with increased susceptibility of $M$. rosenbergii to $L$. garvieae when the prawns were under nitrite stress. In addition to these effects, it would be interesting to determine whether ammonia and/or nitrite stress affect the production of antimicrobial peptides such as penaeidins, which have been observed in the white shrimp Penaeus vannamei (Bachère et al. 2000).

In conclusion, the present study documented that nitrite retarded growth of Lactococcus garvieae and decreased its virulence to Macrobrachium rosenbergii. Nitrite exposure also increased the susceptibility of $M$. rosenbergii to $L$. garvieae, at least partially, by a reduction in immune responses such as decreased phagocytic activity and decreased bacterial clearance efficiency together with increased superoxide anions, possibly to cytotoxic levels for the host.

Acknowledgements. The paper was supported by National Science Council (NSC 90-2313-B-020-019), Republic of China. We thank Miss C. S. Wang for her assistance in the experiment.

\section{LITERATURE CITED}

Adams CM, van der Knapp WPM, Sminia T (1991) Molluscan haemolymph-mediated cytotoxicity: the role of reactive oxygen intermediates. Rev Aquat Sci 4:210-223 
Armstrong DA, Stephenson MJ, Knight AW (1976) Acute toxicity of nitrite to larvae of the giant Malaysian prawn, Macrobrachium rosenbergii. Aquaculture 9:39-46

Arp LH (1988) Bacterial infection of mucosal surfaces: an overview of cellular and molecular mechanisms. In: Roth JA(ed) Virulence mechanisms of bacterial pathogens. American Society for Microbiology, Washington, DC, p 3-27

Bachère E, Destoumieux D, Bulet $P$ (2000) Penaeidins, antimicrobial peptides of shrimp: a comparison with other effectors of innate immunity. Aquaculture 191:71-88

Bayne CJ (1990) Phagocytosis and non-self recognition in invertebrates. Phagocytosis appears to be an ancient line of defense. BioScience 40:723-731

Bell KL, Smith VJ (1993) In vitro superoxide production by hyaline cells of the shore crab Carcinus maenas (L.). Dev Comp Immunol 17:211-219

Bendschneider K, Robinson RJ (1952) A new spectrometric method for the determination of nitrite in the sea water. J Mar Res 11:87-96

Blasco R, Martínez-Luque M, Madrid MP, Castillo F, MorenoVivián C (2001) Rhodococcus sp. RBI grows in the presence of high nitrate and nitrite concentrations and assimilates nitrate in moderately saline environments. Arch Microbiol 175:435-440

Chen JC, Chen SF (1992) Effects of nitrite on growth and molting of Penaeus mondon juveniles. Comp Biochem Physiol C 101: 449-452

Chen JC, Lee Y (1997) Effects of nitrite on mortality, ion regulation and acid-base balance of Macrobrachium rosenbergii at different external chloride concentrations. Aquat Toxicol 39:291-305

Chen SC, Lin YD, Liaw LL, Wang PC (2001) Lactococcus garvieae infection in the giant freshwater prawn Macrobrachium rosenbergii confirmed by polymerase chain reaction and 16S rDNA sequencing. Dis Aquat Org 45: $45-52$

Cheng SY, Chen JC (1998a) Effects of nitrite on the oxygen consumption and ammonia-N excretion of tiger shrimp Penaeus monodon. J Fish Soc Taiwan 25:209-218

Cheng SY, Chen JC (1998b) Effects of nitrite exposure on the hemolymph electrolyte, respiratory protein and free amino acid levels and water content of Penaeus japonicus. Aquat Toxicol 44:129-139

Cheng SY, Chen JC (1999) Hemocyanin oxygen affinity, and the fractionation of oxyhemocyanin and deoxyhemocyanin for Penaeus monodon exposed to elevated nitrite. Aquat Toxicol 45:35-46

Cheng W, Chen JC (1998a) Isolation and characterization of Entercoccus-like bacterium causing muscle necrosis and mortality with Macrobrachium rosenbergii in Taiwan. Dis Aquat Org 34:93-101

Cheng W, Chen JC (1998b) Entercoccus-like infections in Macrobrachium rosenbergii are exacerbated by high $\mathrm{pH}$ and temperature but reduced by low salinity. Dis Aquat Org 34:103-108

Cheng W, Chen JC (1999) Effect of cultivation broth pH, temperature and $\mathrm{NaCl}$ concentration on virulence of an Enterococcus-like bacterium to the giant freshwater prawn Macrobrachium rosenbergii. Dis Aquat Org 36:233-237

Cheng W, Chen JC (2000) Effects of pH, temperature and salinity on immune parameters of the freshwater prawn Macrobrachium rosenbergii. Fish Shellfish Immunol 10: 387-391

Cheng W, Chen JC (2001) Effect of intrinsic and extrinsic factors on the haemocyte profile of the prawn, Macrobrachium rosenbergii. Fish Shellfish Immunol 11:53-63
Cheng W, Chen JC (2002) The virulence of Enterococcus to freshwater prawn Macrobrachium rosenbergii and its immune resistance under ammonia stress. Fish Shellfish Immunol 12:97-109

Cheng W, Wang CH (2001) The susceptibility of the giant freshwater prawn Macrobrachium rosenbergii to Lactococcus garvieae and its resistance under copper sulfate stress. Dis Aquat Org 47:137-144

Direkubusarakom S, Danayadol Y (1998). Effect of oxygen depletion on some parameters of the immune system in black tiger shrimp (Penaeus monodon). In: Flegel RW (ed) Advances in shrimp biotechnology. The National Center for Genetic Engineering and Biotechnology, Bangkok, p 147-149

Doßmann MU, Vogel RF, Hammes WP (1996) Mathematical description of the growth of Lactococcus sake and Lactococcus pentosus under conditions prevailing in fermented sausages. Appl Microbiol Biotechnol 46:334-339

Hernández-López J, Gollas-Galván T, Vargas-Albores F (1996) Activation of the prophenoloxidase system of the brown shrimp (Penaeus californiensis Holmes). Comp Biochem Physiol C 113:61-66

Holmblad T, Söderhäll K (1999) Cell adhesion molecules and antioxidative enzymes in a crustacean, possible role in immunity. Aquaculture 172:111-123

Johansson MW, Söderhäll K (1989) Cellular immunity in crustaceans and the proPO system. Parasitol Today 5:171-176

Kautsky N, Ronnback P, Tedengren M. Troell M (2000) Ecosystem perspectives on management of disease in shrimp pond farming. Aquaculture 191:145-161

Le Moullac G, Haffner P (2000) Environmental factors affecting immune response in Crustacea. Aquaculture 191: 121-131

Le Moullac G, Soyez C, Saulnier D, Ansquer D, Avarre JC, Levy P (1998) Effect of hypoxia stress on the immune response and the resistance to vibriosis of the shrimp Penaeus stylirostris. Fish Shellfish Immunol 8:621-629

Muñoz M, Cedeño R, Roríguez J, van der Knaap WPW, Mialhe E, Bachère E (2000) Measurement of reactive oxygen intermediate production in haemocytes of the penaeid shrimp, Penaeus vannamei. Aquaculture 191:89-107

New MB (1995) Status of freshwater prawn farming: a review. Aquac Res 26:1-54

Prayitno SB, Latchford JW (1995) Experimental infections of crustaceans with luminous bacteria related to Photobacterium and Vibrio. Effect of salinity and $\mathrm{pH}$ on infectiosity. Aquaculture 132:105-112

Ratcliffe NA, Rowley AF, Fitzgerald SW, Rhodes CP (1985) Invertebrate immunity: basic concepts and recent advances. Int Rev Cytol 97:183-350

Regnault M (1987) Nitrogen excretion in marine and freshwater Crustacea. Biol Rev 62:1-24

Roch P (1999) Defense mechanisms and disease prevention in farmed marine invertebrates. Aquaculture 172:125-145

Smith VJ, Johnston PA (1992) Differential haemotoxic effect of PCB congeners in the common shrimp, Crangon crangon. Comp Biochem Physiol C 101: 641-649

Smith VJ, Söderhäll K, Hamilton M (1984) $\beta$-1,3-glucan induced cellular defense reaction in the shore crab, Carcinus maenas. Comp Biochem Physiol A 77: 636-639

Smith VJ, Swindlehurst RJ, Johnston PA, Vethaak AD (1995) Distribution of host defence capability in the common shrimp, Crangon crangon, by exposure to harbour dredge spoils. Aquat Toxicol 32:43-58

Söderhäll K (1983) $\beta$-1,3-glucan enhancement of protease activity in crayfish hemocyte lysate. Comp Biochem Physiol B 74:221-224 
Söderhäll K, Cerenius L, Johansson MW (1996) The prophenoloxidase activating system in invertebrates. In: Söderhäll K, Iwanaga SGR, Vasta GR (eds) New directions in invertebrate immunology. SOS Publications. Fair Haven, NJ, p 229-253

Song YL, Hsieh YT (1994) Immunostimulation of tiger shrimp (Penaeus monodon) hemocytes for generation of microbicidal substances: analysis of reactive oxygen species. Dev Comp Immunol 18:201-209

Sritunyalucksana K, Cerenius L, Söderhäll K (1999) Molecular cloning and characterization of prophenoloxidase in the black tiger shrimp, Penaeus monodon. Dev Comp Immunol 23:179-186

Truscott R, White KN (1990) The influence of metal and temperature stress on the immune system of crabs. Funct Ecol $4: 455-461$

Editorial responsibility: Timothy Flegel,

Bangkok, Thailand
Tsing A, Arcier JM, Brèhèlin M (1989) Haemocytes of penaeids and palaemonid shrimps: morphology, cytochemistry and hemograms. J Invertebr Pathol 53:64-77

Victor B, Narayanan M, Nelson D (1990) Gill pathology and hemocyte response in mercury exposed Macrobrachium idea (Heller). J Environ Biol 11:61-65

Weeks-Perkins BA, Chansue N, Wong-Verelle D (1995) Assay of immune function in shrimp phagocytes: techniques used as indicators of pesticide exposure. In: Stolen J, Fletcher TC, Smith SA, Zelikoff JT, Kaattari SL, Anderson, RS, Söderhäll K, Weeks-Perkins BA (eds) Techniques in fish immunology-4. SOS Publications, Fair Haven, NJ, p 223-231

Weinberg ED (1985) Enzymes, nutrition, and virulence. In: Holder IA (ed) Bacterial enzymes and virulence. CRC Press, Boca Raton, FL, p 1-16

Submitted: November 13, 2001; Accepted: April 17, 2002

Proofs received from author(s): July 9, 2002 